ROCZNIKI HUMANISTYCZNE

Tom LXVIII, zeszyt $12-2020$

DOI: https://doi.org/10.18290/rh206812-6

\title{
NA POGRANICZU LITURGII I CEREMONII. W POSZUKIWANIU SPECYFIKI MUZYCZNEGO OPRACOWANIA HYMNU TE DEUM W TWÓRCZOŚCI JÓZEFA ELSNERA
}

Dziękczynny hymn Te Deum należy - obok Gloria - do najbardziej znanych hymnów świątecznych celebracji liturgicznych. Dzięki walorom poetyckim nazywany jest „perłą psalmodycznej hymniki antycznego Kościoła” (Nadolski 68), natomiast ze względu na treść starochrześcijańskim hymnem uwielbienia Boga albo też hymnem na cześć Trójcy Świętej (hymnus in honorem sanctissimae Trinitatis). Jego powstanie tradycja przypisuje św. Ambrożemu bądź też wspólnie św. Ambrożemu i św. Augustynowi, stąd też często bywa on określany „hymnem ambrozjańskim” (Hymnus ambrosianus). Nowsze badania podważają jednak to autorstwo. Obecnie przyjmuje się, iż tekst hymnu Te Deum powstawał przez dłuższy okres czasu, a jego ostateczna wersja zredagowana została w końcu $\mathrm{V}$ wieku przez nieznanego autora (zob. Nadolski 71-76; Gamber 318-321).

W dziejach muzyki hymn Te Deum należał do najczęściej opracowywanych poetyckich tekstów religijnych od wczesnego stadium rozwoju twórczości wielogłosowej aż po czasy współczesne. Do nurtu tego przynależy m.in. pochodzące z roku 1815 opracowanie Józefa Elsnera (1769-1854), które stanowi główny przedmiot rozważań niniejszego artykułu. W publikacjach poświęconych twórczości tego kompozytora wielokrotnie podkreślałem jego związek

Prof. dr hab. REMIGIUSz PoŚPIECH - Uniwersytet Wrocławski, Wydział Nauk Historycznych i Pedagogicznych, Instytut Muzykologii, Zakład Muzykologii Historycznej; adres do korespondencji: ul. Szewska 36, 50-139 Wrocław; e-mail: remigiusz.pospiech@uwr.edu.pl. ORCID: https:// orcid.org/0000-0001-5859-0734.

Prof. dr habil. REMigiusz PoŚPIECH - The University of Wrocław, Faculty of Historical and Pedagogical Sciences, Institute of Musicology, Department of Historical Musicology; address for correspondence: ul. Szewska 36, 50-139 Wrocław, Poland; e-mail: remigiusz.pospiech@uwr.edu.pl. ORCID: https://orcid.org/0000-0001-5859-0734. 
z bogatą tradycją kultury muzycznej Śląska, na terenie którego się urodził i gdzie przeszedł pierwsze etapy edukacji. W kontekście tym zwracałem przede wszystkim uwagę na obecność w jego dorobku charakterystycznych dla tej tradycji gatunków, jak Stacje na Boże Ciało czy Te Deum (Pośpiech, Muzyka wielogłosowa 126-136, 238-241; „Nova et vetera” 358-362 i „Musica Nova Ecclesiastica" 110-113). Prezentowana kompozycja Elsnera, biorąc pod uwagę zarówno inspirację jej powstania, dedykację, jak i styl opracowania muzycznego, sytuuje się na pograniczu świeckich ceremonii oraz liturgicznych celebracji. Dlatego też w tym kontekście podjęta zostanie próba przedstawienia ogólnej charakterystyki analizowanego utworu, a zarazem ukazania jego specyfiki na tle rozwoju muzycznych opracowań Hymni ambrosiani. Z powodu wymogów wynikających z ram artykułu ograniczę moje rozważania do tych zagadnień, które wydają się być najbardziej istotne. Po krótkiej prezentacji samego hymnu Te Deum, w aspekcie liturgicznym i muzycznym, wskażę na jego znaczenie w opracowaniach kompozytorów związanych z szeroko rozumianą kulturą muzyczną Śląska ${ }^{1}$, by przejść do ogólnej analizy kompozycji Elsnera. Jej podstawą będą źródłowe przekazy (drukowana partytura i rękopiśmienna kopia) zachowane w archiwum klasztornym oo. paulinów na Jasnej Górze.

\section{LITURGICZNE I POZALITURGICZNE FUNKCJE TE DEUM}

Pierwotnie, od ok. V-VI wieku, Te Deum było hymnem paschalnym. Następnie wykonywano go na zakończenie Liturgii Godzin (bezpośrednio przed sprawowaniem Eucharystii) w niedziele i święta poza okresem Adwentu i Wielkiego Postu. W późniejszym okresie rozwinął się zwyczaj jego śpiewania jako responsorium po 9. lub 3. lekcji Jutrzni w te dni, w których podczas Mszy św. śpiewano Gloria ${ }^{2}$ (Nadolski 76; Harper 95-115; Kirsch, „Te Deum laudamus" 1336). Warto podkreślić, iż omawiany hymn obecny jest w liturgicznym repertuarze wszystkich kościołów chrześcijańskich. Występuje, na przykład, w porannym oficjum liturgii bizantyjskiej, stanowi część porannej modlitwy w Common Book of Prayer, natomiast w kościelnych wspólnotach ewangelickich wykonuje się go podczas błogosławienia paschału, jak również w ramach innych świąt i uroczystych okoliczności (Nadolski 76-77; Aplin 247-253; Halamska 54-56).

\footnotetext{
${ }^{1}$ W rozważaniach na temat hymnu Te Deum oraz znaczenia jego opracowań muzycznych w rozwoju tradycji muzycznej Śląska wykorzystane zostaną wyniki moich wcześniejszych badań (Pośpiech, „Dziękczynny hymn”, „Die mehrstimmigen Bearbeitungen” i Muzyka wieloglosowa 131-136).

${ }^{2} \mathrm{Z}$ wyjątkiem Wielkiego Czwartku.
} 
We wszystkich wspomnianych wyżej wyznaniach chrześcijańskich Te Deum kojarzone jest powszechnie jako hymn dziękczynny (pro gratiarum actione), który śpiewany był również przy okazji różnych uroczystości, zarówno kościelnych (np. synody, wybory hierarchów, intronizacje, kanonizacje, translacje relikwii, jubileusze itp.), jak i świeckich (np. koronacje królewskie, zaślubiny władców, narodziny potomków królewskich, dziękczynienia za zwycięstwa ważnych bitew itp.). Podniosły i uroczysty charakter hymnu, wykonywanego często $\mathrm{z}$ towarzyszeniem bicia dzwonów i wykraczającego poza pierwotne przeznaczenie liturgiczne, znany był już w epoce karolińskiej i rozwijany w okresie średniowiecza (Žak 1-28; Nadolski 77-80). Natomiast czasem szczególnego rozkwitu reprezentacyjnych funkcji Te Deum był okres baroku, w którym to przywiązywano wielką wagę do obrzędowości i ceremoniału także w ramach liturgii, pełnej bogactwa i wystawnej różnorodności (Gerhard 65-66, 73-76; Riedel, „Kirchenmusik als politische Repräsentation” 117-121; Pośpiech, „Theatrum musicum” 142-144, 150-151).

Od strony treści w hymnie Te Deum, liczącym w sumie 29 wersów ${ }^{3}$, wyróżnia się najczęściej trzy części: pierwsza poświęcona jest Bogu Ojcu (uważana za najstarszą), druga Jezusowi Chrystusowi, trzecia natomiast stanowi błagalne prośby w intencji wiernych. Czasem jeszcze wyodrębniane są z pierwszej części wersy 11-13, jako forma doksologii - uwielbienia Trójcy Świętej (Nadolski 68-70, 81-101; Magne 113-118; Nohl 180-186).

\section{OPRACOWANIA MUZYCZNE TE DEUM (DO KOŃCA XVIII WIEKU)}

Tradycja monodii liturgicznej przechowała przede wszystkim dwie, stosunkowo proste i dość schematyczne melodie śpiewane do prezentowanego tekstu: tonus solemnis i tonus simplex (Liber usualis 1832-1837). Znane są ponadto dwa inne tony: tonus juxta morem Romanum i tonus monasticus (spotykany w antyfonarzach monastycznych), a także wersja tzw. chorału mediolańskiego (Gastoué 129-135; Schumacher 103). Pierwsze polifoniczne opracowania Te Deum powstały w XV wieku, a zachowane przykłady źródłowe pochodzą głównie z terenu Anglii i Niemiec (Kirsch, Die Quellen 57-69 i „Varianten” 118-129; Caldwell 188-191). Stosunkowo długi tekst i wspomniana wyżej różnorodność zawartych w analizowanym hymnie treści dawały kompozytorom sporo możliwości jego podziału, a w konsekwencji, formalnego strukturowania. Stąd też

\footnotetext{
${ }^{3}$ Wersy 22-29 są najprawdopodobniej późniejszym dodatkiem, stąd też nie są dziś obowiązkowe (odmawiane bądź śpiewane ad libitum).
} 
pośród opracowań wielogłosowych spotykamy opracowania od jedno- do wieloczęściowych. W okresie renesansu utwory tego gatunku początkowo komponowane były najczęściej w stylu motetowym, nierzadko z wykorzystaniem tzw. praktyki alternatim, czyli śpiewu naprzemiennego (poszczególne wersy wykonywano na przemian chorałowo i wielogłosowo bądź też wokalnie i instrumentalnie, dzieląc odcinki na jedno- lub wielogłosowe i partie organowe), a pod koniec tej epoki także z wykorzystaniem polichóralności (Kirsch, „Zur Kompositionstechnik” 23-25, 34-57 i „Te Deum” 433-437).

Szczególny rozkwit twórczości wielogłosowej wykorzystującej tekst Hymnum ambrosianum obserwujemy w epoce baroku wraz z rozwojem wokalno-instrumentalnego stile concertato. Ówczesne opracowania tekstu Te Deum przybierały coraz częściej formę muzyki typowo okolicznościowej, związanej zarówno z uroczystościami religijnymi, jak i państwowymi (tzw. „Staatsmusik”). Wtedy też coraz powszechniejsza staje się pozaliturgiczna funkcja omawianego hymnu. Należy jednak pamiętać, iż pomimo rozbudowywania omawianych kompozycji w zakresie rozmiarów i obsady (szczególnie zespołu instrumentalnego, z obligatoryjnym udziałem trąbek i kotłów) oraz ich funkcjonowania na pograniczu sacrum i profanum, zasadniczo rozbrzmiewały one we wnętrzach kościelnych i prawie zawsze towarzyszyło im bicie dzwonów, a w prezentacjach plenerowych nawet armatnie wystrzały ${ }^{5}$ (Žak 28-32; Riedel, Kirchenmusik am Hofe 200-205 i „Kirchenmusik als politische Repräsentation" 117-126). Od połowy XVIII stulecia zaobserwować możemy tendencje do uproszczenia struktury muzycznej, przy zachowaniu jednak uroczystego charakteru tych dzieł ${ }^{6}$. Odzwierciedlały one z jednej strony użytkową funkcję ówczesnych kompozycji liturgicznych, z drugiej natomiast ilustrują oddziaływanie wprowadzanych w tym okresie tzw. reform józefińskich (Kirsch, „Te Deum” 437-438; Pauly 376-380).

Podsumowując syntetyczny rys rozwoju polifonicznych opracowań hymnu Te Deum, możemy stwierdzić, że dla kompozycji tego gatunku najbardziej

\footnotetext{
${ }^{4}$ Można tu wymienić kompozycje tak znanych twórców, jak: Ludwig Senfl, Clemens non Papa, Jacobus Gallus (Handl), Jacobus de Kerle, Tomás Luis de Victoria, Orlando di Lasso, Luca Marenzio czy Constanzo Festa. Do tego nurtu zaliczyć można także powstałe na przełomie XVI i XVII wieku kompozycje twórców protestanckich, m.in. Michaela Praetoriusa, Johanna Hermanna Scheina oraz Heinricha Schütza.

${ }^{5}$ Do tego nurtu zaliczyć możemy kompozycje takich twórców, jak: Jean-Baptiste Lully, Marc-Antoine Charpentier (4 różne opracowania), Henry Purcell, Georg Friedrich Händel (5), Antonio Caldara (4), Johann Joseph Fux (6), Johann Adolf Hasse (4), Franz Xaver Richter (2), Carl Heinrich Graun (1) czy Niccoló Jomelli (3).

${ }^{6}$ Reprezentują je m.in. kompozycje Michaela Haydna, Josepha Haydna, Wolfganga Amadeusa Mozarta czy Antonina Reichy.
} 
istotny był okres od połowy XVII do początków XIX stulecia. Z tego właśnie czasu pochodzi najwięcej przykładów charakteryzujących się bogatą różnorodnością ukształtowań muzycznych. Duża część z nich zachowała się w archiwach kościelnych i miejskich na terenie całej Europy. Znakomitą tego ilustrację stanowi ciągle uzupełniany katalog Répertoire International des Sources Musicales (RISM), który pod hasłem Te Deum zawiera ponad 8000 rekordów (niektóre kompozycje zachowały się w kilku, a nawet kilkunastu odpisach), z czego ponad połowa pochodzi z wyróżnionego wyżej okresu. Pośród nich znajdują się przekazy źródłowe omawianego utworu Elsnera. Przed jego szczegółową analizą przedstawimy jeszcze ogólny rys rozwoju opracowań hymnu Te Deum w kontekście bogactwa tradycji kultury muzycznej Śląska.

\section{TE DEUM W TRADYCJI RELIGIJNEJ KULTURY MUZYCZNEJ ŚLĄSKA}

Omówione wyżej najbardziej istotne aspekty liturgiczno-muzycznej tradycji Te Deum znajdujemy również w rozwoju liturgii i muzyki kościelnej na Śląsku, gdzie omawiany hymn pełnił podobne funkcje, religijne i świeckie. Zachowane księgi liturgiczne potwierdzają zasadniczo zwyczaje typowe dla całego Kościoła rzymskokatolickiego, zarówno w odniesieniu do liturgii przedtrydenckiej, jak i większym jeszcze stopniu potrydenckiej (Pośpiech, „Dziękczynny hymn” 121-132) ${ }^{7}$.

Tradycję śląskich opracowań wielogłosowych rozpoczyna Te Deum urodzonego w Świdnicy wikariusza katedry wrocławskiej Thomasa Stolzera (ok. 1475-1526), jednego z wybitniejszych przedstawicieli muzyki wczesnego renesansu ${ }^{8}$. Charakterystyczne, że w źródłach śląskich (głównie wrocławskich) pochodzących z XVI i początku XVII wieku spotykamy dzieła tego gatunku zarówno twórców miejscowych bądź związanych z terenem Śląska, jak i obcych, na czele z najwybitniejszymi muzykami europejskimi ${ }^{9}$. Należy

\footnotetext{
${ }^{7}$ Uroczyste wykonania hymnu Te Deum w ramach liturgii w największe uroczystości roku kościelnego (głównie Liturgia Paschalna i Oktawa Wielkanocna, a także uroczystości Bożego Ciała oraz Bożego Narodzenia) możliwe były - co oczywiste - w tych kościołach, w których funkcjonowały na co dzień odpowiednie zespoły muzyków - śpiewaków i instrumentalistów, czyli przede wszystkim w katedrach, kolegiatach i najważniejszych opactwach.

${ }^{8}$ Dzieło to, utrzymane w tzw. praktyce alternatim, należy do najwcześniejszych opracowań muzycznych omawianego gatunku; informacje o jego wykonaniach spotykamy m.in. w pochodzącym z 1524 r. spisie repertuaru zespołu muzycznego wrocławskiego kościoła św. Marii Magdaleny (Pośpiech, „Dziękczynny hymn” 122-123).

9 Pierwszych reprezentują m.in. Johannes Knöfel (ok. 1540-po 1617) czy Thomas Fritsch (15631619), drugich z kolei, przykładowo, Jacobus de Kerle (1531-1591), Orlando di Lasso (1532-1594),
} 
ponadto podkreślić, iż pośród autorów tych kompozycji znajdujemy przedstawicieli obydwu współistniejących w tym regionie wyznań: katolickiego i protestanckiego, a ponadto w poszczególnych opracowaniach wykorzystywano tekst łaciński (najczęściej) oraz niemiecki. To wszystko potwierdza wskazywaną wielokrotnie w odniesieniu do Śląska (szczególnie Wrocławia) swoistą ekumenię muzyczną (Pośpiech, „Breslau” 7-10, 15). Zachowane informacje źródłowe z XVII i pierwszej połowy XVIII wieku potwierdzają, iż także na omawianych terenach hymn Te Deum coraz częściej wykonywany był poza swoim liturgicznym przeznaczeniem $\mathrm{w}$ ramach rozmaitych uroczystości religijnych i świeckich. Te powszechne w całej Europie tendencje spotykamy przede wszystkim w stolicy regionu, a zarazem diecezji - we Wrocławiu, ale również w innych większych miastach, jak np. Legnica, Brzeg czy Nysa (Pośpiech, „Dziękczynny hymn” 124-125; Halamska 54-57, 69-70).

W drugiej połowie XVIII i na początku XIX stulecia śląską tradycję opracowań Te Deum w środowisku katolickim kontynuował głównie długoletni kapelmistrz wrocławskiej katedry Johann Georg Clement (ok. 1709-1794) ${ }^{10}$, pielęgnowali ją także liczni kompozytorzy klasztorni. Warto w tym miejscu zwrócić uwagę na zachowaną kolekcję muzykaliów pochodzącą z dawnego klasztoru bożogrobców w Nysie, która stanowi jeden z najliczniejszych, nie tylko na Śląsku, zbiorów wielogłosowych opracowań tekstu Te Deum (Pośpiech, „Die mehrstimmigen Bearbeitungen” 472-477). W sumie posiadamy informacje o trzydziestu kompozycjach, spośród których do dziś zachowało się dwadzieścia pięć ${ }^{11}$. Utwory te dobitnie potwierdzają popularność omawianego hymnu w ówczesnym repertuarze muzyki religijnej na Śląsku, a także obrazują fakt jego uroczystych wykonań z udziałem chóru i kapeli muzycznej, co było powszechną praktyką w całym Kościele katolickim, szczególnie w okresie kontrreformacji (Pospiech, Muzyka wielogłosowa 135-136). Z punktu widzenia tematyki artykułu istotna jest dla nas obecność kompozycji twórców śląskich, którzy przyczyniali się do transferu ww. specyficznych cech rozwoju

Lodovico Balbi (ok. 1545-1604), Christoph Demantius (1567-1643), Michael Praetorius (15711621), Johann Hermann Schein (1586-1630) i Daniel Bollius (ok. 1590-1642).

Na uwagę zasługuje tu przeznaczone na rozbudowany zespół wokalno-instrumentalny polichóralne Te Deum Tobiasa Zeutschnera (1621-1675), kantora kościoła św. Bernardyna, utrzymane w reprezentatywnym stylu utworów okolicznościowych (Halamska 61-65).

${ }^{10}$ Pośród jego stosunkowo licznej (ponad 150 tytułów) twórczości zachowały się trzy opracowania Te Deum (wszystkie w tonacji D-dur). Powstałe w II połowie XVIII wieku utwory wykorzystują łaciński tekst hymnu i przeznaczone są na 4-głosowy zespół wokalny, 2 skrzypiec, 2 trąbki i organy.

${ }^{11}$ Przykładowo, w najliczniejszym na terenie Polski zbiorze muzykaliów jasnogórskich zachowało się jedenaście kompozycji tego gatunku, a w źródłach po kapeli katedralnej w Gnieźnie zaledwie trzy. 
omawianego gatunku na rodzimy teren diecezji wrocławskiej ${ }^{12}$. Dodajmy jeszcze, iż podobne stylistycznie oraz formalnie kompozycje, o analogicznej funkcji i przeznaczeniu, tworzone i wykonywane były także w innych ośrodkach kościelnych (głównie klasztornych) na Śląsku ${ }^{13}$. Jedną z najbardziej specyficznych cech zachowanego repertuaru jest opracowanie wersu 22: Salvum fac populum tuum Domine et benedic haereditati tuae, który wyróżniony jest zazwyczaj poprzez wolne tempo (najczęściej adagio) oraz skromne opracowanie muzyczne (np. prosta deklamacja tekstu a cappella, a nawet unisono całego zespołu), bądź też w ogóle nie jest opracowany (w niektórych manuskryptach widnieje jedynie uwaga: Salvum fac tacet). Stanowi to zapewne egzemplifikację rozpowszechnionego na Śląsku, znanego także m.in. w Polsce i Czechach, zwyczaju, iż wers ten śpiewał kapłan, błogosławiąc trzykrotnie zgromadzonych wiernych (Sobeczko 130, 372). Ponadto kompletne wykorzystanie łacińskiej wersji tekstu w większości omawianych kompozycji wyraźnie wskazuje na ich liturgiczne przeznaczenie, co w niektórych źródłach potwierdza dołączony na końcu wers Benedicamus Patrem et Filium cum Sancto Spiritu Laudemus et superexaltemus eum in saecula, który śpiewany jest po hymnie Te Deum w liturgii niedzielnej i świątecznej w okresie zwykłym roku kościelnego.

Spośród wspomnianych wyżej kompozytorów na szczególną uwagę zasługuje długoletni kapelmistrz wrocławskiej katedry Joseph Ignatz Schnabel. Jego utwory cieszyły się na omawianym terenie największą popularnością. Można je także uznać za najwartościowsze od strony muzycznej, co sprawiło, że ich recepcja sięga XX wieku. Pośród pięciu różnych opracowań Te Deum tego twórcy znajdujemy zarówno kompozycje typowo użytkowe - zwięzłe, jednoczęściowe, wymagające niewielkiego zespołu wykonawczego, jak i dzieła o charakterze okolicznościowym - bardziej rozbudowane, kilkuczęściowe, przeznaczone na większy zespół wykonawczy (Urban 367-373). W tym samym okresie co Schnabel we Wrocławiu swoje kompozycje pisał Elsner w Warszawie. Te ostatnie, powstałe do tekstu liturgicznego hymnu Te Deum, będą przedmiotem szczegółowej analizy w zasadniczej części niniejszych rozważań.

${ }^{12}$ Spotykamy tu zarówno nazwiska powszechnie znane, np. Carl Joseph Birnbach (17511805) czy Joseph Ignatz Schnabel (1767-1831), jak i twórców o lokalnym jedynie znaczeniu, do których należą: Johann Michael Kirchner (ok. 1752-1802), Joseph Latzel (1764-1827), Constantin Bach (ok. 1768-1805), Joseph Hanisch (zm. 1802), Joseph Grüger (zm. 1814) oraz August Volckmer (XVIII/XIX wiek).

${ }^{13}$ Można tu wymienić nazwiska takich twórców, jak: Andreas Gölner (1689-1758), Johann Gottlieb Janitsch (1708-1763), Johann Carl Baudisch (zm. 1764), Franz Beinlich (ok. 1731-1777), Franz Ziegenheim (poł. XVIII wieku) czy Alois Bach (1770-1845). 


\section{TE DEUM JÓZEFA ELSNERA}

Elsner opracował tekst omawianego hymnu trzykrotnie, w różnych okresach działalności twórczej (1815, ok. 1825 i 1842), o czym wspomina w spisanym pod koniec życia Sumariuszu:

1) „Te Deum laudamus (in D) na 4 głosy śpiewne i orkiestrę, przypisane Najjaśniejszemu Cesarzowi Aleksandrowi I, jako Królowi Polskiemu; w 1815 roku wykonane po raz pierwszy w kościele Ks. Pijarów przez Towarzystwo Muzykalne, sztychowane w Lipsku u Breitkopfa i Härtla, za które otrzymałem od Jego Cesarskiej Mości pierścień brylantowy” (Elsner $34 \mathrm{nr} 11$ );

2) „Te Deum laudamus na 4 głosy z kotłami i trąbami (ad libitum), przypisane radcy stanu Marcinowi Zaleskiemu, u Płacheckiego" (36 nr 39);

3) „Te Deum laudamus z tekstem greckim [w rzeczywistości jest tekst rosyjski; uzup. aut. RP] na obchód srebrnego wesela Ich Cesarskich Mości” (39 $\mathrm{nr} 74)$.

Najbardziej interesująca jest niewątpliwie najwcześniejsza z wymienionych kompozycji, począwszy od inspiracji jej powstania, poprzez dedykację, rozbudowaną obsadę i kunsztowne opracowanie muzyczne, aż po jej recepcję. Utwór ten, opublikowany w 1815 r. w znanym wydawnictwie Breitkopfa i Härtla w Lipsku (nr wyd. 2362), należał do najbardziej rozpowszechnionych dzieł kompozytora i stosunkowo długo utrzymywał się w repertuarze zespołów kościelnych oraz świeckich, o czym dobitnie świadczą zachowane źródła: dziewięć egzemplarzy pierwodruku ${ }^{14}$ oraz autograf partytury (w opracowaniu na sopran i bas solo z towarzyszeniem organów, zachowanym w Bibliotece Warszawskiego Towarzystwa Muzycznego, sygn. R.930) i jedenaście rękopiśmiennych kopii, najczęściej w postaci głosów, sporządzonych w latach 1815-ok. $1860^{15}$. Podstawą dalszych szczegółowych analiz będą - jak wspomniano na początku - przekazy źródłowe zachowane w archiwum klasztornym oo. paulinów na Jasnej Górze: pierwodruk partytury (PL-Cz D III-46) oraz jej rękopiśmienna kopia (PL-Cz III-171), sporządzona w styczniu 1830 r. przez jasnogórskiego kapelistę (w latach 1828-1832) Józefa Czaykowskiego ${ }^{16}$ (Podejko 156-157, 800). Obydwa źródła posiadają prawie identyczne brzmienie

\footnotetext{
${ }^{14}$ Pięć w Niemczech (Akwizgran, Berlin, Coburg, Kolonia, Lipsk) oraz po jednym w Polsce (Jasna Góra), Austrii (Melk), Czechach (Brno) i Francji (Paryż). Dziękuję Paulinie Halamskiej za pomoc w identyfikacji zachowanych przekazów źródłowych analizowanej kompozycji.

${ }^{15}$ Sześć kopii zachowało się w bibliotekach na terenie Polski (Gniezno, Jasna Góra, Kraków - 2, Warszawa - 2, w tym jeden odpis ze zbiorów po kapeli jezuickiej w Kłodzku), oraz cztery w Niemczech (Akwizgran, Coburg, Lipsk - tylko głosy wokalne, Tegernsee), natomiast jedna w Rosji (Moskwa).

${ }^{16}$ Na końcu partii Tenore widnieje inskrypcja: Scripsit J. Czaykowski |d. 24. Stycznia 1830 r. | Fine.
} 
karty tytułowej, choć występują pomiędzy nimi drobne różnice, dotyczące głównie pisowni:

- druk: Post celebrem ex hoste victoriam | stabilitam Europae pacem | restitutamque suo nomini et rei Poloniam | tantorum operum auspici $\mid$ Alexandro I | Omnium Russiarum Imperatori et Polonorum Regi | HYMNUM AMBROSIANUM | NOVA MUSICA | DIE VI CAL. JUL. MDCCCXV VARSAVIAE | in ecclesia scholarum piarum decantatum | nomine instituti musici $|D D D|$ fidelis subditus $\mid$ JOSEPHUS ELSNER | Lipsiae | Impensis Breitkopfii \& Härtelii.

- rękopis: Te Deum laudamus: | Post celebrem ex hoste victoriam | stabilitam Europae pacem | restitumque suo nomini et rei Poloniam. | tantorum operum auspici. | Alexandro. $I^{\text {mo }} \mid$ Omnium Róssiarum [!] Imperatori et Polonorum Regi. | Hymnum Ambrosyantum [!] Nowa Musyka [!] | Die VI Cal. Jul. M.D.CCCXV. Varsavie. | in ecclesia scholarum piarum decantatum | nomine instituti musici. | D. D. D. | fidelis subditus. | Josephus Elsner. | Lipsiae | Impensis Breitkopfii et Härtelii.

Rozbudowany tytuł kompozycji wyraźnie wskazuje, iż jej bezpośrednią inspiracją były wydarzenia polityczne związane ze zwycięstwem nad Napoleonem (Post celebrem ex hoste victoriam) oraz z obradami Kongresu Wiedeńskiego (1814-1815), w wyniku których nastąpił względny pokój i na nowo zdefiniowana została mapa Europy (stabilitam Europae pacem restitutamque), z obecnością na niej Królestwa Polskiego (proklamowanego 20 czerwca 1815 r.), choć ściśle uzależnionego od Rosji (car był jednocześnie królem Polski) ${ }^{17}$. Historyk Jerzy Zdrada stwierdza, że: „utworzenie Królestwa Polskiego było dla narodu polskiego rozwiązaniem najlepszym z możliwych po klęsce Napoleona. Okrojono terytorium Księstwa [Warszawskiego; uzup. aut. RP], ale utrzymano polską państwowość. Z ulgą przyjęły to elity polityczne i szerokie rzesze patriotycznego społeczeństwa. Decydowała nadzieja na spełnienie obietnicy Aleksandra I połączenia Królestwa z ziemiami zabranymi” (93). I choć oczekiwania te nie zostały spełnione, to jednak w początkowym okresie car - jako Omnium Russiarum Imperatori et Polonorum Regi cieszył się przychylnością niemałej liczby Polaków, w tym także wielu osób prominentnych (Zdrada 85-103; Nowak-Romanowicz 133-134). Do grona tego należał, jak można sądzić, również Elsner ${ }^{18}$, który obok analizowanego

\footnotetext{
${ }^{17}$ Warto zauważyć, iż w tym samym roku i z tej samej okazji swoje Te Deum na dwa chóry i orkiestrę dedykował Aleksandrowi I także Józef Kozłowski (1757-1831).

${ }^{18}$ Istotnym niewątpliwie był tu także fakt, iż do najbliższych politycznych partnerów Aleksandra I należał ks. Adam Jerzy Czartoryski, z którym Elsner współpracował m.in. przy powoływaniu do istnienia Towarzystwa Przyjaciół Muzyki Kościelnej i Narodowej (Elsner 33 nr 8; Nowak-Romanowicz 137-139, 204; Mączyński 43-52).
} 
utworu skomponował m.in. niezachowaną „Kantatę na dzień urodzin J. C. Mości Cesarza Aleksandra I, Króla Polskiego" (Elsner 50 nr 14), zaś po śmierci władcy Requiem in c minor (36 $\mathrm{nr} 42$ ). Charakterystyczny jest tu także przytoczony w Sumariuszu opis sytuacji politycznej stolicy ówczesnego Księstwa na początku XIX wieku: „W roku 1809, gdy Austriacy zajęli Warszawę, nastał nowy stan rzeczy, wszakże ja, po staremu, nie mogłem trafić do ładu, aż nareszcie w roku 1813 dostaliśmy się pod ojcowskie panowanie błogosławionej pamięci cesarza Aleksandra I" (127). Należy jednak zauważyć inne jeszcze powody zamieszczania na kartach tytułowych dzieł Elsnera dedykacji, bardziej przyziemne, materialne. Wskazują na to chociażby uwagi kompozytora w Sumariuszu, dopowiadane często po tytułach utworów. W przypadku Te Deum jest to zacytowana już wyżej uwaga: „(...) za które otrzymałem od Jego Cesarskiej Mości pierścień brylantowy” (34) ${ }^{19}$. Warto ponadto przywołać $\mathrm{w}$ tym miejscu stwierdzenie $\mathrm{z}$ końcowych ustępów wspomnień naszego twórcy, skierowane już wprawdzie do następcy cara Aleksandra - Mikołaja $\mathrm{I}^{20}$, dobrze jednak oddające oczekiwania od ówczesnych władców, które dotyczyły nie tylko spraw politycznych i wzniosłych idei, ale też życia codziennego: „Dzięki na koniec Najjaśniejszemu Cesarzowi Wszech Rosji i Królowi Polskiemu, który ustawę tak dobroczynną najwyżej uświęcić i zatwierdzić raczył, a na mocy której pobieram dziś 9860 złotych pensji emerytalnej, którą nie tylko jako sowitą nagrodę za moje usiłowania i czynności poczytuję, ale za pośrednictwem której jestem dziś w stanie pędzić resztę dni moich z przyjemnym zadowoleniem i w zupełnej spokojności!" (179-180).

W Te Deum Elsnera niezwykle istotny jest jeszcze jeden fragment karty tytułowej dzieła: HYMNUM AMBROSIANUM | NOVA MUSICA | DIE VI CAL. JUL. MDCCCXV VARSAVIAE | in ecclesia scholarum piarum decantatum | nomine instituti musici. Poza zwyczajowym określeniem opracowania jako hymnu ambrozjańskiego widać wyraźnie, że pomimo iż mamy do czynienia z kompozycją powstałą z inspiracji wydarzeń świeckich (politycznych), o charakterze typowo okolicznościowym, utrzymaną w stylu ceremonialnym

${ }^{19}$ Jeszcze bardziej znamienna jest tu uwaga zamieszczona po wspomnianym wyżej Requiem: „(...) za każdy egzemplarz tegoż dostałem od N. Króla Pruskiego, od N. Cesarza Austriackiego i od Najjaśniejszego Cesarza Mikołaja I po pierścieniu brylantowym, od księcia zaś Antoniego Radziwiłła pismo dziękczynne" (Elsner $36 \mathrm{nr}$ 42). Dodajmy, iż Elsner dedykował swoje utwory także innym władcom, m.in. Napoleonowi, Fryderykowi Augustowi I i Fryderykowi Wilhelmowi III.

${ }^{20}$ Władcy temu dedykował Elsner m.in. Mszę solenna in $C$, wykonaną w warszawskiej katedrze 24 maja 1929 r. podczas uroczystości koronacyjnych, za którą - jak czytamy w Sumariuszu - „dostałem od N. Cesarza Mikołaja I tabakierkę złotą” (37 nr 51). 
(z trąbkami i kotłami) ${ }^{21}$, funkcjonowała ona jednak w ramach celebracji liturgicznych, w określonym dniu i w określonym miejscu: w niedzielę 25 czerwca 1815 r. $^{22}$ w warszawskim kościele oo. pijarów przy ul. Długiej siłami Towarzystwa Przyjaciół Muzyki Kościelnej i Narodowej. Wiadomo, że w tej świątyni wykonywano stosunkowo często dzieła religijne Elsnera, który utrzymywał przyjazne kontakty z zakonem Szkół Pobożnych, a po pożarze swojego majątku w Elsnerowie wynajmował u nich dwie cele w starym klasztorze przy ul. Jezuickiej (Mączyński 62-64). Omawiane dzieło zabrzmiało ponownie w listopadzie 1815 r., w czasie pobytu Aleksandra I w stolicy (Nowak-Romanowicz 206). Niewykluczone ponadto, że zachowana w formie rękopiśmiennego autografu uproszczona wersja utworu na sopran bas i organy przeznaczona była dla potrzeb wymienionego wyżej Towarzystwa w latach, gdy nie posiadało ono odpowiednich sił wykonawczych ${ }^{23}$.

Dalsze wykonania Te Deum Elsnera na terenie Królestwa Polskiego ilustrują m.in. zachowane źródła klasztoru oo. paulinów na Jasnej Górze. Warto w tym miejscu podkreślić, iż w zbiorach jasnogórskich zachowała się największa część dorobku religijnego omawianego twórcy, w sumie ponad 40 utworów, w większości manuskryptów, częściowo także druków (kilka równocześnie w postaci druków i ich rękopiśmiennych kopii), wśród nich nawet takie, które długo uchodziły za zaginione (Muchenberg i Podejko 17-28). Niektóre kompozycje związane były bezpośrednio z kultem maryjnym bądź też dedykowane zostały władzom zakonu paulińskiego. Poświadcza to z jednej strony bliskie kontakty kompozytora z klasztorem na Jasnej Górze, z drugiej natomiast ilustruje żywotną recepcję twórczości religijnej omawianego muzyka (Pietras 150-151, 153; Pośpiech, „Msze polskie” 135-137). Szczegółowa analiza stanu zachowania wymienionych wyżej źródeł oraz znajdujących się w nich inskrypcji pozwala stwierdzić, iż Te Deum in D Elsnera dobrze wpisywało się w liturgiczno-muzyczną tradycję tego ośrodka,

\footnotetext{
${ }^{21}$ Obsada utworu jest następująca: sopran, alt, tenor, bas (z partiami solowymi w S i B), dwoje skrzypiec, altówka, wiolonczela, kontrabas, po dwa flety, oboje, klarnety, fagoty, rogi i trąbki (Clarini), puzon oraz kotły. W wykonaniach jasnogórskich brały ponadto udział organy, o czym świadczą dopiski „Senza Organo” i „tasto solo” na kartach głosu Basso e Violoncello (występujące także w przekazie z Biblioteki Jagiellońskiej).

${ }^{22} \mathrm{Na}$ karcie tytułowej podana jest data 6 lipca według obowiązującego wtedy w Rosji (i na ziemiach jej podległych) kalendarza juliańskiego (Mączyński 49).

${ }^{23}$ W statucie Towarzystwa Przyjaciół Muzyki Kościelnej i Narodowej znajdujemy jedynie ogólną informację (rozdz. 5, s. 4), że: „Uroczystość doroczna ustanowienia Towarzystwa obchodzona będzie zawsze dnia 12 stycznia przez odegranie mszy wielkiej nowej i hymnu Te Deum” (Mączyński 82).
} 
w którym wielogłosowe opracowania tego hymnu rozbrzmiewały przy różnych uroczystych okazjach ${ }^{24}$ (Pośpiech, „Wkład paulinów” 672-673).

Struktura architektoniczna analizowanej kompozycji jest stereotypowa (podobnie jak kontrasty agogiczne, tonalne i metryczne) i wynika $z$ treści tekstu. Całość składa się z następujących części:

$\begin{array}{lllc}\text { Te Deum laudamus } & \text { Allegro moderato } & \text { D-dur } & 4 / 4 \\ \text { Salvum fac } & \text { Andante } & \text { B-C-D } & {[4 / 4]} \\ \text { Et rege eos } & \text { Allegro tempo primo } & \text { D-dur } & 4 / 4 \\ \text { Dignare Domine } & \text { Più lento di tempo primo } & \text { g-moll } & 4 / 4 \\ \text { In te Domine speravi } & \text { Allegro tempo primo } & \text { D-dur } & \text { alla breve }\end{array}$

Część zasadnicza, stanowiąca hymn pochwalny Trójcy Świętej, utrzymana jest w uroczystym, hymnicznym charakterze, prawie w całości w tutti. Możemy tu jednak wyróżnić kilka kontrastujących, także fakturalnie, zawsze uzasadnionych treściowo ustępów. Na uwagę zasługują przede wszystkim odcinki imitacyjne na słowach omnis terra, charakterystyczny i oryginalny zarazem odcinek a cappella aklamacji Sanctus, Sanctus, Sanctus (z dodatkowym określeniem sotto voce oraz rozdzielającymi poszczególne słowa fanfarami instrumentów dętych), pary głosów łączące się najpierw z chórami apostołów i proroków (Te gloriosus apostolorum chorus), później zaś z wymienianiem przymiotów boskich (Tu Rex gloria, Christe. Tu Patris sempiternus es Filius), czy wreszcie wyraźna zmiana klimatu - na błagalny, połączona $\mathrm{z}$ kontrastem fakturalnym i urozmaiceniem harmoniki wraz $\mathrm{z}$ wersem Te ergo quesumus. Kończąca pierwszą część utworu modulacja (D-d-F) przygotowuje utrzymany w podobnym klimacie fragment Salvum fac, stanowiący modlitewne prośby o błogosławieństwo i opiekę Opatrzności. Zauważmy w tym miejscu, że o ile pierwsza część tekstu (w sumie 21 wersów) opracowana została w formie jednego, rozbudowanego wprawdzie i zróżnicowanego wewnętrznie, ustępu, to końcowe osiem wersów podzielonych zostało aż na cztery oddzielne, wyraźnie wyróżnione fragmenty.

\footnotetext{
${ }^{24} \mathrm{~W}$ zbiorach jasnogórskich zachowały się przekazy dziesięciu wielogłosowych opracowań hymnu Te Deum (5 rękopiśmiennych, 2 drukowane oraz $2 \mathrm{w}$ postaci druku i jego odpisu). Dwa pochodzą z II połowy XVIII wieku (Anton Bauer i Franz Xaver Brixi), siedem z pierwszych trzech dekad wieku XIX (Józef Elsner, Joseph Ohnewald, Johann Baptist Schiedermayr, Johann Carl Strobl i trzy anonimowe), natomiast jeden z II połowy tego stulecia (Franz Xaver Witt).
} 
Pierwszy z nich - Salvum fac - należy niewątpliwie do najbardziej oryginalnych w całej kompozycji. Elsner zastosował tu, występującą także w późniejszych kompozycjach (np. Lauda Jeruzalem z nieszporów maryjnych), technikę specyficznego opracowania psalmodii (zmodyfikowany ton 8), śpiewanej przez chór unisono na tle wytrzymywanych akordów instrumentów smyczkowych granych - jak zaznaczono $\mathrm{w}$ partyturze - tremolando recitativo ${ }^{25}$. Charakterystyczne jest tu także trzykrotne powtórzenie całego wersu, za każdym razem o ton wyżej (F-G-A) ${ }^{26}$, co wyraźnie nawiązuje do wspomnianego wyżej, rozpowszechnionego także na Śląsku, liturgicznego zwyczaju błogosławienia w tym czasie zgromadzonych wiernych Przenajświętszym Sakramentem.

W dalszym przebiegu utworu na szczególniejszą uwagę zasługuje imitacyjne, nawiązujące do wcześniejszych tradycji opracowanie wersu Et rege eos z fugą na słowach in saeculum saeculi, a także opracowanie wersu Dignare, Domine, rozpoczynające się sotto voce declamando, z wyraźną figurą exclamatio przy słowach miserere nostri Domine oraz z rozbudowanymi partiami solowymi sopranu i basu, które prowadzą linię melodyczną na tle deklamacyjnego unisonu chóru (z dodatkowymi określeniami pregando, calando czy cantando w głosie solowym). Ostatni fragment - In te Domine speravi-motywicznie, tonalnie i agogicznie nawiązuje do początkowego odcinka utworu.

Porównując zaprezentowane Te Deum Elsnera z innymi kompozycjami tego gatunku, można dostrzec wyraźny związek $\mathrm{z}$ tradycją habsburską (austriacko-czeską). Warto podkreślić, iż stosunkowo dużo tego rodzaju utworów zachowało się na terenie Śląska, kulturowo powiązanego z tymi ośrodkami, co obrazują np. zbiory po kapeli bożogrobców w Nysie czy ośrodków klasztornych Wrocławia. Wiadomo, że twórca nasz związany był z tym regionem: tu się urodził i tu spędził okres młodości, w tym lata edukacji muzycznej. Omawiane dzieło Elsnera, poprzez wskazaną na karcie tytu-

${ }^{25}$ Podobne ukształtowania spotykamy także w innych opracowaniach tego hymnu, np. w zachowanym w zbiorach nyskich Te Deum śląskiego twórcy Augusta Volckmera czy niemieckiego kompozytora Johanna J. Emmerta, a ponadto w Vesperae chorales nyskiego muzyka Josepha Latzela, z którym twórca nasz utrzymywał przyjacielskie kontakty (Pośpiech, „Die mehrstimmige Bearbeitungen" 474-475)

${ }^{26} \mathrm{~W}$ głosie Violino Primo znajduje się oddzielna karta, stanowiąca rodzaj wyciągu z partytury, z unisonową melodią i podpisanym pod nią tekstem w głosie wyższym (określonym jako „Orchester”) i akordami w głosie niższym (oznaczonym „Violino”, z dodatkowym zaznaczeniem w odpowiednich miejscach wejść instrumentów dętych: „Oboe” i „Fagott”). 
łowej zarówno okoliczność oraz dedykację, jak i sposób opracowania, mieści się wyraźnie w nurcie kompozycji okolicznościowych, choć przeznaczonych do wykonania podczas liturgicznych celebracji, charakterystycznych przede wszystkim dla twórczości europejskiej XVIII stulecia. Zauważmy jeszcze na koniec, iż na karcie tytułowej analizowane Te Deum oznaczone zostało jako Nova Musica, którym to określeniem kompozytor sygnował część dzieł religijnych (Pośpiech, „Musica Nova Ecclesiastica” 115-118). Pragnął wskazać w ten sposób, jak można sądzić, na istotną wartość swoich kompozycji, które na tle ogólnego poziomu ówczesnej muzyki kościelnej w Polsce wyraźnie się wyróżniały i wniosły znaczący wkład w jej dalszy rozwój.

\section{BIBLIOGRAFIA}

Aplin, John. „The Survival of Plainsong in Anglican Music: Some Early English Te-Deum Settings." Journal of the American Musicological Society, vol. 32, 1979, ss. 247-253.

Elsner, Józef. Sumariusz moich utworów muzycznych z objaśnieniami o czynnościach i działaniach moich jako artysty muzycznego, red. Alina Nowak-Romanowicz, Polskie Wydawnictwo Muzyczne, 1957.

Gamber, Klaus. „Das »Te Deum« und sein Autor.” Revue Bénédictine, vol. 74, 1964, ss. 318-321.

Gerhard, Albert. „Te Deum laudamus - die Marseillaise der Kirche? Ein christlicher Hymnus im Spannungsfeld von Liturgie und Politik.” Liturgisches Jahrbuch, Bd. 40, 1990, ss. 65-77.

Halamska, Paulina. „Wielogłosowe opracowania hymnu »Te Deum laudamus« w kościołach protestanckich siedemnastowiecznego Wrocławia. Przyczynek do historii gatunku w epoce baroku". Muzyka, nr 3, 2011, ss. 51-81.

Harper, John. Formy i układ liturgii zachodniej od X do XVIII wieku. Tłum. Małgorzata Kowalska. Wydawnictwo Musica Iagellonica, 1997.

Kirsch, Winfried. Die Quellen der mehrstimmige Magnificat- und Te Deum Vertonungen bis zur Mitte des 16. Jahrhunderts. Hans Schneider Verlag, 1966.

Kirsch, Winfried. „Te Deum laudamus”. Lexikon für Theologie und Kirche, 2 Aufl., Bd. 9, Verlag Herder, 1964, s. 1336.

Kirsch, Winfried. „Te Deum. II. Mehrstimmige Kompositionen.” Die Musik in Geschichte und Gegenwart. Zweite, neubearbeitete Ausgabe. Sachteil, hrsg. von Ludwig Finscher, Bd. 9, Bärenreiter-Verlag, 1998, ss. 433-440.

Kirsch, Winfried. „Varianten und Fragmente des liturgischen Te Deum - Textes in den mehrstimmigen Kompositionen des 15. und 16. Jahrhunderts." Kirchenmusikalisches Jahrbuch, Bd. 48, 1964, ss. 118-134.

Kirsch, Winfried. „Zur Kompositionstechnik der mehrstimmigen Alternatim - Te Deum im 15. und 16. Jahrhundert." Anuario Musical, no. 22, 1967, ss. 19-63.

Liber usualis. Missae et Officii pro Dominicis et Festis cum canto gregoriano. Desclée \& Socii, 1934.

Magne, Jean. „Carmina Christo. II. Le Te Deum.” Ephemerides Liturgicae, t. 100, 1986, ss. 113-137.

Mączyński, Ryszard. W kręu kultury zakonnej Warszawy XVII-XIX wieku. Wydawnictwo Naukowe Uniwersytetu Mikołaja Kopernika, 2018. 
Muchenberg, Bohdan, i Paweł Podejko. „Nieznane rękopisy i druki kompozycji Józefa Elsnera.” Z Dziejów Muzyki Polskiej, t. 10, 1965, ss. 13-30.

Nadolski, Bogusław. Chwała Ojcu. Doksologie w liturgii. Wydawnictwo PALLOTINUM, 1999.

Nohl, Paul-Gerhard. Lateinische Kirchenmusiktexte, 2 Aufl., Bärenreiter-Verlag, 1998.

Nowak-Romanowicz, Alina. Józef Elsner. Monografia. Polskie Wydawnictwo Muzyczne, 1957.

Pauly, Reinhard. „The Reforms of Church Music under Joseph II.” Musical Quarterly, vol. 43, 1957, ss. 372-382.

Podejko, Paweł. Katalog tematyczny rękopisów i druków muzycznych kapeli wokalno-instrumentalnej na Jasnej Górze. Wydawnictwo OO. Paulinów, 1992.

Pośpiech, Remigiusz. „Breslau als Zentrum der Musikkultur Schlesiens im 17. Jahrhundert.” Schütz-Jahrbuch, t. 32, 2010, ss. 7-15.

Pośpiech, Remigiusz. „Die mehrstimmigen Bearbeitungen des Hymnus Te Deum in der Musikaliensammlung der St.-Peter-und-Paul-Kirche (Kreuzherrenkirche) in Neisse.” Musikgeschichte zwischen Ost- und Westeuropa. Kirchenmusik - geistliche Musik-religiöse Musik, hrsg. von Helmut Loos i Klaus-Peter Koch, Studio Verlag 2002, ss. 465-477.

Pośpiech, Remigiusz. „Dziękczynny hymn Te Deum w śląskiej tradycji muzycznej”. Ut mysterium paschale vivendo exprimatur. Księga pamiatkowa dedykowana księdzu profesorowi Helmutowi Janowi Sobeczce, red. Tadeusz Dola i Rudolf Pierskała, Redakcja Wydawnictw Wydziału Teologicznego Uniwersytetu Opolskiego, 2000, ss. 115-133.

Pośpiech, Remigiusz. „Musica Nova Ecclesiastica Józefa Elsnera (1769-1854) na tle polskiej muzyki religijnej XIX stulecia”. Tradycje ślaskiej kultury muzycznej. Tom XI, red. Anna Granat-Janki [i in.], Wydawnictwo Akademii Muzycznej im. Karola Lipińskiego we Wroclawiu, 2008, ss. 107-120.

Pośpiech, Remigiusz. „Msze polskie Józefa Elsnera (1769-1854) ze zbiorów jasnogórskich”. Donum natalicum. Studia Thaddaeo Przybylski octogenario dedicata, red. Zofia Fabiańska [i in.], Wydawnictwo Musica Iagellonica, 2007, ss. 131-147.

Pośpiech, Remigiusz. Muzyka wielogłosowa w celebracji eucharystycznej na Ślasku w XVII i XVIII wieku. Redakcja Wydawnictw Wydziału Teologicznego Uniwersytetu Opolskiego, 2004.

Pośpiech, Remigiusz. „Nova et vetera w twórczości Józefa Elsnera (1769-1854)”. Ad Christianorum Unitatem Fovendam. Księga pamiatkowa dedykowana Księdzu Arcybiskupowi Alfonsowi Nossolowi Wielkiemu Kanclerzowi Wydziału Teologicznego Uniwersytetu Opolskiego, red. Stanisław Rabiej, Redakcja Wydawnictw Wydziału Teologicznego Uniwersytetu Opolskiego, 2007, ss. 353-367.

Pośpiech, Remigiusz. „Theatrum musicum w liturgii okresu baroku”. Liturgia $w$ świecie widowisk, red. Helmut J. Sobeczko i Zbigniew W. Solski, Redakcja Wydawnictw Wydziału Teologicznego Uniwersytetu Opolskiego, 2005, ss. 141-155.

Pośpiech, Remigiusz. „Wkład paulinów w rozwój kultury muzycznej Środkowej Europy”. Studia Claromontana, t. 27, 2009, ss. 671-686.

Riedel, Friedrich W. „Kirchenmusik als politische Repräsentation. Zur Vertonung des »Te Deum laudamus« im 18. und 19. Jahrhundert." Festschrift für Winfried Kirsch zum 65. Geburtstag, hrsg. von Peter Ackermann [i in.], Hans Schneider Verlag, 1996, ss. 117-129.

Riedel, Friedrich W. Kirchenmusik am Hofe Karls VI. (1711-1740). Untersuchungen zum Verhältnis von Zeremoniell und musikalischen Stil im Barockzeialter. Musikverlag Emil Katzbichler, 1977. 
Schumacher, Gerhard. „Te Deum.” Das Grosse Lexikon der Musik, hrsg. von Marc Honnegger i Günther Massenkeil, Bd. 8, Herder Verlag, 1982, ss. 103-104.

Sobeczko, Helmut Jan. Liturgia katedry wrocławskiej wedtug przedtrydenckiego Liber Ordinarius z 1563 roku. Wydawnictwo Św. Krzyża, 1993.

Urban, Mariusz. Twórczość religijna Josepha Ignatza Schnabla w kontekście przemian stylistycznych muzyki przełomu XVIII i XIX wieku. Rozprawa doktorska, Uniwersytet Adama Mickiewicza w Poznaniu, Poznań, 2019.

Zdrada, Jerzy. Historia Polski 1795-1914. Wydawnictwo Naukowe PWN, 2007.

Žak, Sabine. „Das Te Deum als Huldigungsgesang.” Historisches Jahrbuch, Bd. 102, 1982, ss. 1-32.

\title{
NA POGRANICZU LITURGII I CEREMONII. \\ W POSZUKIWANIU SPECYFIKI MUZYCZNEGO OPRACOWANIA HYMNU TE DEUM W TWÓRCZOŚCI JÓZEFA ELSNERA
}

\section{Streszczenie}

Opublikowane w 1815 r. i zadedykowane carowi Aleksandrowi I Te Deum Józefa Elsnera ilustruje nurt opracowań tekstów religijnych, których funkcję rozpatrywać można zarówno w kontekście liturgicznych celebracji, jak i świeckich ceremonii. Kompozycja ta wpisuje się z jednej strony w bogate tradycje muzyki kościelnej Śląska, z którą kompozytor był związany z racji urodzenia i wykształcenia, z drugiej natomiast odzwierciedla stan rozwoju XIX-wiecznej kultury muzycznej w Polsce, z którą związał większą część swojego życia. Analizowana kompozycja, przeznaczona na głosy solowe, chór mieszany oraz orkiestrę, składająca się z pięciu skontrastowanych części, stylistycznie utrzymana jest w nurcie twórczości religijnej charakterystycznej dla terenów Europy Środkowej przełomu XVIII i XIX stulecia, które zaobserwować możemy także winnych dziełach Elsnera.

Słowa kluczowe: Te Deum; hymn; muzyka religijna; Józef Elsner; car Aleksander I.

\author{
ON THE BORDER BETWEEN LITURGY AND CEREMONY. \\ IN SEARCH OF THE SPECIFICS OF MUSICAL ARRANGEMENT \\ OF THE HYMN TE DEUM IN THE WORKS OF JÓZEF ELSNER
}

\section{Summary}

Published in 1815 and dedicated to Tsar Alexander I, Te Deum by Józef Elsner illustrates the trend of religious texts, the function of which can be considered in the context of liturgical celebrations as well as secular ceremonies. On the one hand, this composition is part of the rich traditions of Silesian church music, which the composer was associated with by birth and education. On the other hand, it reflects the state of the development of the $19^{\text {th }}$ century musical culture in Poland, which the greater part of his life was associated with. The compositions mentioned in the article, intended for solo voices, mixed choir and orchestra, consist of five contrasted parts, and are stylistically maintained in the trend of the religious creativity characteristic of Central Europe at the turn of the eighteenth and nineteenth centuries, which can also be seen in a number of other works by Elsner.

Key words: Te Deum; hymn; religious music; Józef Elsner; Alexander I of Russia. 